\title{
Modern and Glacial-Holocene Carbonate Sedimentation in Bear Lake, Utah-Idaho
}

Open-File Report 2005-1124 


\title{
Modern and Glacial-Holocene Carbonate Sedimentation in Bear Lake, Utah-Idaho
}

\author{
By Walter Dean', Richard Forester1, Steven Colman², An Liu33, Gary Skipp', \\ Kathleen Simmons ${ }^{1}$, Peter Swarzenski ${ }^{4}$, and Roger Anderson ${ }^{5}$
}

\footnotetext{
${ }^{1}$ U.S. Geological Survey, Box 25046, MS 980 Federal Center, Denver, CO 80225

2 U.S. Geological Survey, 384 Woods Hole Road, Woods Hole, MA 02543

${ }^{3}$ University of Minnesota, St. Paul, MN 55108

${ }^{4}$ U.S. Geological Survey, St. Petersburg, FL 33701

${ }^{5}$ Department of Earth and Planetary Sciences, University of New Mexico, Albuquerque, NM 87131
}

Open-File Report 2005-1124

\section{U.S. Department of the Interior \\ U.S. Geological Survey}




\section{U.S. Department of the Interior \\ Gale A. Norton, Secretary}

\section{U.S. Geological Survey \\ P. Patrick Leahy, Acting Director}

U.S. Geological Survey, Reston, Virginia: 2005

For sale by U.S. Geological Survey, Information Services

Box 25286, Denver Federal Center

Denver, CO 80225

For more information about the USGS and its products:

Telephone: 1-888-ASK-USGS

World Wide Web: http://www.usgs.gov/

Any use of trade, product, or firm names in this publication is for descriptive purposes only and does not imply endorsement by the U.S. Government.

Although this report is in the public domain, permission must be secured from the individual copyright owners to reproduce any copyrighted materials contained within this report.

Suggested citation:

Dean, W., Forester, R., Colman, S., Liu, A., Skipp, G., Simmons, K., Swarzenski, P., Anderson, R., and Thornburg, D., 2005, Modern and glacial-Holocene carbonate sedimentation in Bear Lake, Utah-Idaho: U.S. Geological Survey OpenFile Report 2005-1124, 18 p.

Prepared by the U.S. Geological Survey in Denver, Colorado (http://esp.cr.usgs.gov/) 


\title{
Modern and Glacial-Holocene Carbonate Sedimentation in Bear Lake, Utah-Idaho
}

\author{
By Walter Dean, Richard Forester, Steve Colman, An Liu, Gary Skipp, Kathleen Simmons, Peter Swarzenski, \\ and Roger Anderson
}

\section{Introduction}

The Bear Lake Valley in northeastern Utah and adjacent Idaho (fig. 1) is a half graben containing a mesosaline-alkaline lake (Bear Lake). The lake is $32 \mathrm{~km}$ long and 6-13 km wide with an area of $280 \mathrm{~km}^{2}$ at full capacity. Maximum depth is $63 \mathrm{~m}$, with a mean depth of $28 \mathrm{~m}$ (Birdsey, 1989). The present elevation of the lake is 1805 meters above sea level (masl), but this level has varied considerably through time. The natural watershed of the lake is relatively small, with a basin-area: lake-area ratio of only 4.8:1 (Wurtsbaugh and Luecke, 1997). Historically, the Bear River did not flow into Bear Lake. A series of canals, built from 1909 to 1918 (Birdsey, 1989), now diverts the Bear River into Bear Lake creating a reservoir to supply irrigation water downstream. This increased the basinarea:lake-area ratio considerably to $29.5: 1$. The mean annual surface hydrologic flux (including precipitation) to the lake is $0.48 * 10^{9} \mathrm{~m}^{3} / \mathrm{yr}$ (Lamarra and others, 1986), which is only about 6 percent of the lake volume $\left(7.86 * 10^{9} \mathrm{~m}^{3}\right)$, giving an average residence time of about 16 years. The magnitude of ground water influx is not known.

Kullenberg piston coring in 1996 and seismic profiling in 1997 and 2002 (fig. 1) reveal a layered sediment package with clear wedging reflectors and erosional unconformities (fig. 2). The piston cores recovered highly resolved records with excellent definition of geochemical-climate proxies and low-sedimentation rates. They are only a maximum of $5 \mathrm{~m}$ in length but provide a 30,000-year record, well beyond the last glacial maximum. Some unknown amount of sediment was missing from the tops of the piston cores so surface sediments (up to $50 \mathrm{~cm}$ ) were collected with a gravity corer (1998; fig. 1). The Holocene sediments are carbonate-rich (predominantly aragonite), and the glacial-age sediments consist of calcareous silty clays, probably indicating direct inflow of Bear River into Bear Lake.

The seismic stratigraphy below the lake (fig. 2) indicates that the principal structure is a half graben, with a steep normal-fault margin on the east and a ramp margin on the west. Seismic reflections diverge toward the master fault, bounding eastward thickening sediment wedges. Secondary normal faults west of the master fault were imaged beneath the lake, and many of these faults show progressively increasing throw with depth and age. Several faults cut the youngest sediments in the lake as well as the modern lake floor. Although pinchouts of sedimentary units are common in relatively shallow water, no major erosional or depositional features suggestive of shoreline processes were observed on seismic profiles in water deeper than about $5 \mathrm{~m}$.

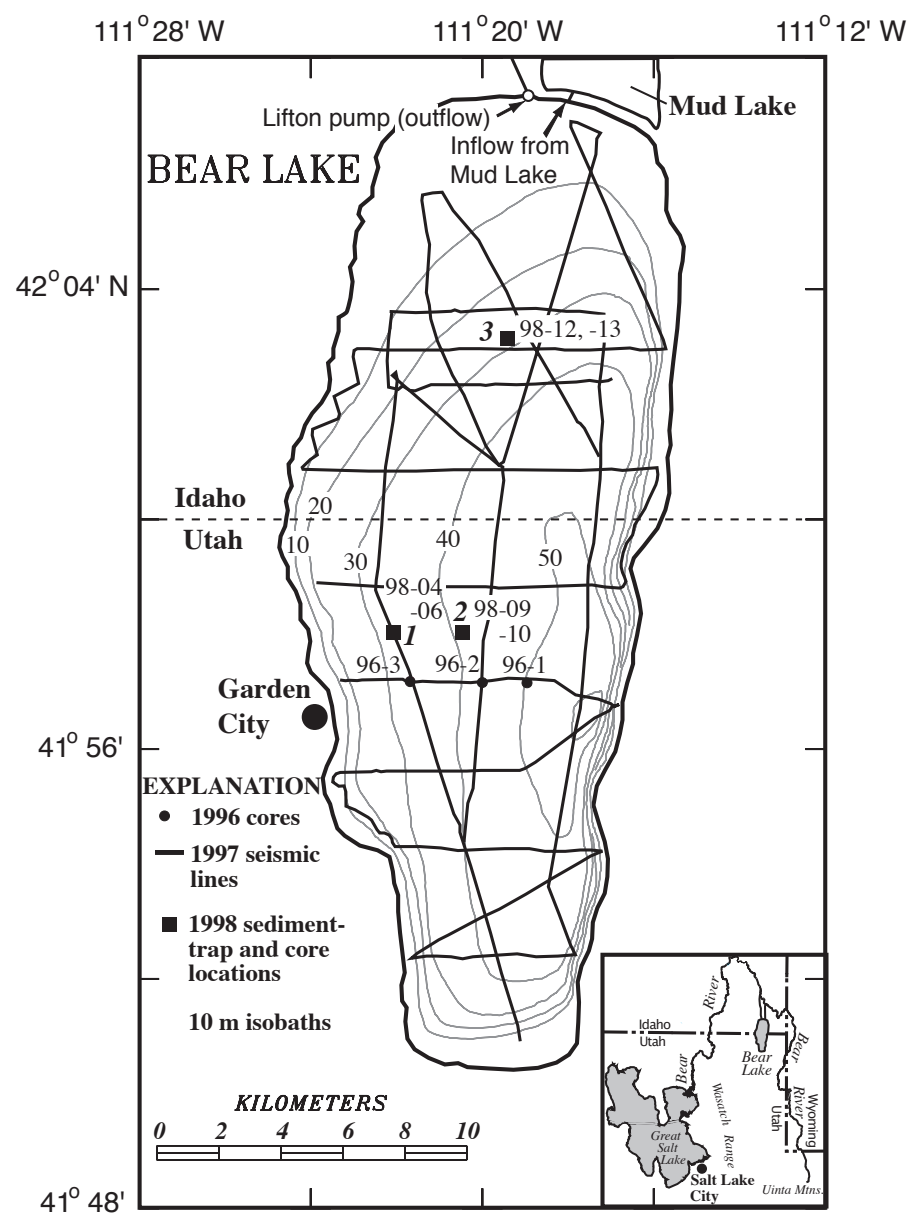

Figure 1. Bathymetric map of Bear Lake Utah/Idaho, showing the locations of 1996 piston cores $(96-1,-2,-3), 1997$ seismic lines, and 1998 surface-sediment cores $(98-04,-06,-09,-10,-12,-13)$ and sediment-trap deployments $1,2,3$ ). Inset shows the location of Bear Lake relative to Bear River and Great Salt Lake. 


\section{Water Chemistry}

Samples of water from Bear Lake and streams and springs around the lake were collected in September 1999 (fig.3). Major and trace elements in these samples were measured by inductively coupled argon-plasma emission spectrometry (ICP) at the University of Minnesota. Values of ${ }^{87} \mathrm{Sr} /{ }^{86} \mathrm{Sr}$ were measured by mass spectrometry at the Isotope Geochemistry Laboratories of the U.S. Geological Survey (USGS) in Denver, Colorado. Additional samples of water from Bear Lake and streams and springs around the lake were collected in August 2000 (fig. 3). Major and trace elements in these samples were measured by ICP at the USGS National Water Quality Laboratory in Denver. Values of ${ }^{87} \mathrm{Sr} /{ }^{86} \mathrm{Sr}$ were measured by mass spectrometry at the Isotope Geochemistry Laboratories of the USGS in Denver, Colorado.

The dominant cations in Bear Lake water today are calcium $(\mathrm{Ca})$, magnesium $(\mathrm{Mg}$,) and sodium $(\mathrm{Na})$ (Appendix 1). The dominant anion is bicarbonate, but with relatively high concentrations of sulfate $\left(\mathrm{SO}_{4}\right)$ and chloride $(\mathrm{Cl})$ (Appendix 1). A cross plot of $\mathrm{Mg}$ concentration versus $\mathrm{Ca}$ concentration (fig. 4) shows that Bear Lake is highly enriched in Mg relative to Bear River. As seen on Figure 4, the chemistry of the outflow from Bear Lake can be explained by a simple mixture of Bear Lake and Bear River waters.

The concentration of $\mathrm{Mg}$ in Bear Lake was much greater prior to the diversion of Bear River into Bear Lake between 1909 and 1918 (Appendix 1, fig. 4), and the net effect of the diversion was to dilute Bear Lake water. Figure 4 shows the progression of dilution over the past 90 years. The $\mathrm{Mg}$ :Ca ratio in the Bear Lake water sample collected in 1912 (Kemmerer and others, 1923) was 38:1; today it is about 1.7:1 (Appendix
1). There must be a large Mg-rich ground-water source from a deep aquifer because shallow ground waters, as sampled in springs and wells around the lake, have compositions similar to surface waters.

The Sr-isotope story of Bear Lake and associated waters is somewhat different. Figure 5 shows that the outflow from Bear Lake can be explained by a mixture of Bear Lake water with a low Sr concentration and Bear River water with a high Sr oncentration, but the isotopic composition of $\mathrm{Sr}$ in the two waters is not greatly different. This indicates that the suspected $\mathrm{Mg}$-enriched ground-water source has a low $\mathrm{Sr}$ concentration. Other potential sources of Sr-depleted water are the west-side creeks (fig. 5), although they are extremely enriched in ${ }^{87} \mathrm{Sr}$ relative to the lake and east-side streams, including Bear River.

\section{Analytical Methods for Sediments}

Concentrations of total carbon (TC) and inorganic carbon (IC) in splits of the XRD samples were determined by coulometric titration of $\mathrm{CO}_{2}$ following extraction from the sedimentby combustion at $950^{\circ} \mathrm{C}$ and acid volatilization, respectively (Engleman and others, 1985), in USGS laboratories, Denver, Colorado. Weight percent IC was converted to weight percent $\mathrm{CaCO}_{3}$ by dividing by 0.12 , the fraction of carbon in $\mathrm{CaCO}_{3}$. Organic carbon (OC) was determined by difference between TC and IC. Results of analyses of samples from surface gravity cores are given in Appendix 3, and those from the longer piston cores are given in Appendix 7.1. and 7.2.

Semiquantitative estimates of mineral contents of powdered bulk samples were determined by standard X-ray diffraction (XRD) techniques (for example, Moore and Reynolds,

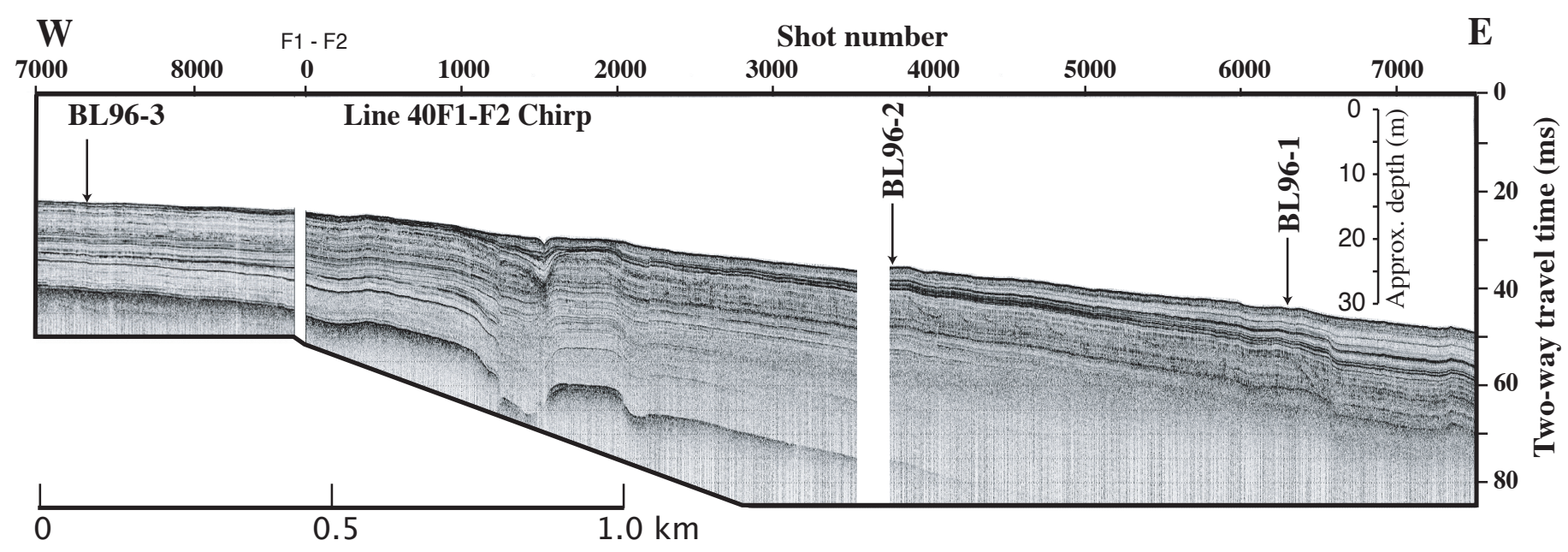

Figure 2. Chirp seismic profile collected in 2002 across Bear Lake from Garden City, Utah showing the locations of 1996 piston cores. Two-way travel time is in milliseconds. The location of the chirp line is approximately the same as the1997 acoustic-reflection line west of Garden City, Utah in Figure 1 showing the locations of the three cores. 


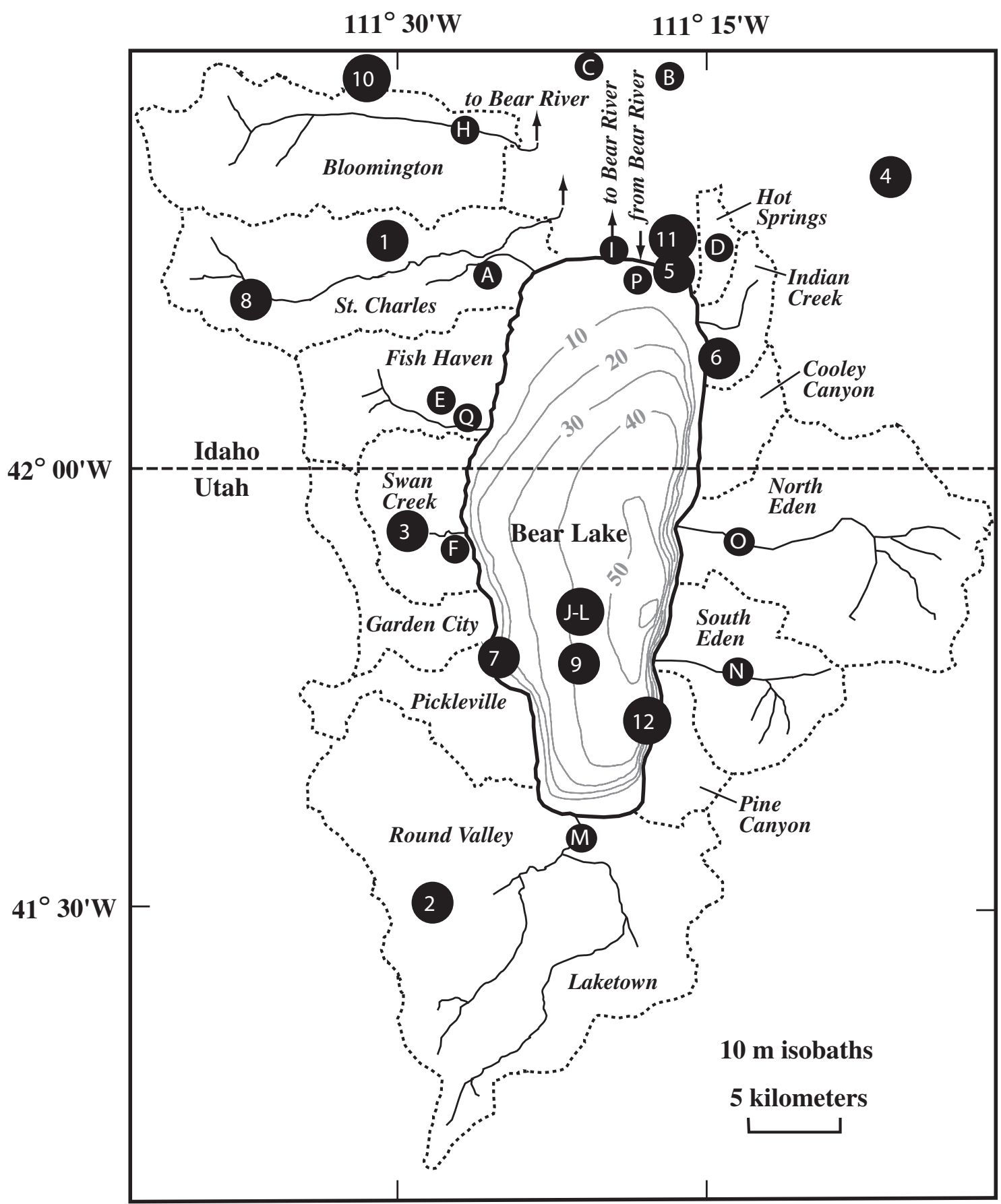

Figure 3. Map of Bear Lake and surrounding drainages showing the water samples collected in 1999 (letters) and 2000 (numbers). Analyses of these samples are given in Table 1.

1989) in USGS laboratories, Denver, Colorado. Each sample was packed into an aluminum holder and scanned from $15^{\circ}$ to $50^{\circ} 2 \Theta$ at $2^{\circ} 2 \Theta /$ min using Ni-filtered, $\mathrm{Cu}-\mathrm{Ka}$ radiation at 45 $\mathrm{kv}, 30$ ma. Raw XRD peak intensities, in counts per second, for the main peaks of minerals detected in each sample were converted to semiquantitative percentages by dividing the main peak intensity of a mineral by the sum of the main peak intensities of all minerals for that particular sample. These percentage calculations should be used with caution, because they do not reflect the different X-ray mass absorption characteristics of different minerals. Results of these calculations for samples from surface gravity cores are given in Appendix 4, and those from the longer piston cores are given in Appendix 8.1, 8.2., and 8.3. 


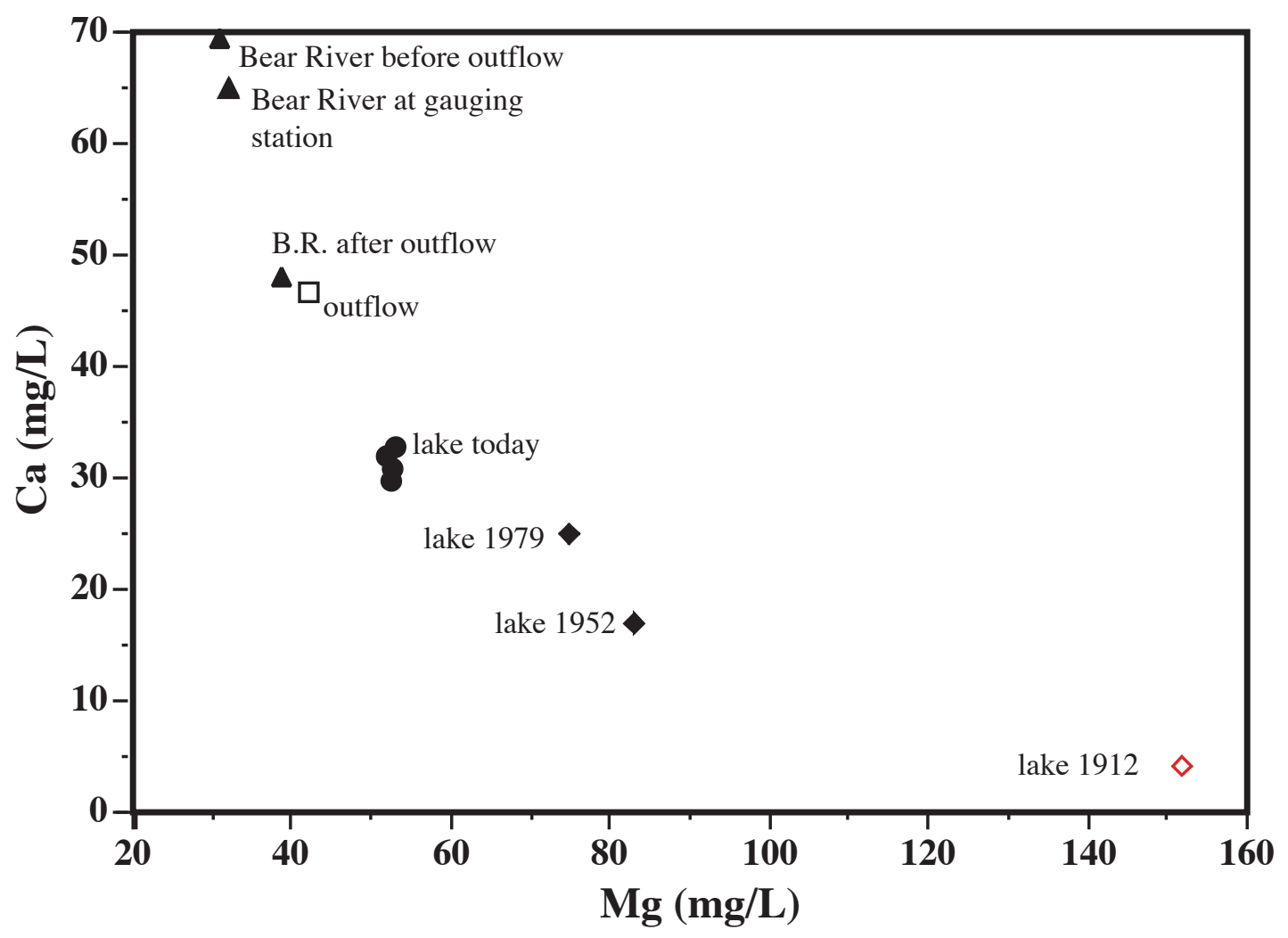

Figure 4. Cross plots of concentrations of $\mathrm{Mg}$ and $\mathrm{Ca}$ in Bear Lake and associated waters. All values are from Table 1.

Samples for measurement of ratios of stable isotopes of carbon and oxygen were collected from each core at $5 \mathrm{~cm}$ intervals, and treated with 0.25 percent Calgon for $2 \mathrm{hr}$ to disaggregate the sediment. The samples then were sieved through a $60 \mu \mathrm{m}$ sieve into $50 \mathrm{~mL}$ centrifuge tubes. About $15 \mathrm{~mL}$ commercial bleaching liquid (a 5 percent solution of sodiumhyperchlorite) was added to oxidize organic material for 24 hours. The mixture then was centrifuged for about 5 minutes. The liquid was decanted and the residue saved. The residue from each sample was freeze-dried and ground to a powder. Based on carbonate content, a calculated amount of sample, containing about $10 \mathrm{mg}$ of calcium carbonate, was reacted with 100 percent phosphoric acid at $75 \pm 1^{\circ} \mathrm{C}$. Evolved gases were cryogenically purified to remove water and noncondensible gases. The purified $\mathrm{CO}_{2}$ was introduced into a Finnigan MAT delta E mass spectrometer through a capillary, and isotopic ratios of carbon and oxygen were measured against a reference standard of known isotopic composition. Results of analyses are reported in the usual per mil (\%o) $\delta$-notation relative to the Vienna Pee Dee Belemnite (VPDB) marine-carbonate standard for carbon and oxygen:

$\delta \%_{0}=[($ Rsample/RVPDB $)-1] \times 10^{3}$ (where $\mathrm{R}$ is the ratio ${ }^{13} \mathrm{C}:{ }^{12} \mathrm{C}$ or $\left.{ }^{18} \mathrm{O}:{ }^{16} \mathrm{O}\right)$.
Results of analyses of samples from surface gravity cores are given in Appendix 5, and those from the longer piston cores are given in Appendix 9.1., 9.2., and 9.3.

Samples for measurement of strontium isotope ratios were leached in 5 molar acetic acid. The leachate was centrifuged and purified with conventional ion-exchange methods. Samples were loaded on a single tantalum filament with phosphoric acid. Isotope ratios were measured with an automated VG54 sector multicollector, thermal-ionization mass spectrometer in dynamic mode. Mass dependent fractionation was corrected assuming a ${ }^{86} \mathrm{Sr} /{ }^{87} \mathrm{Sr}$ of 0.1194 . Strontium isotope ratios are reported relative to SRM-987 standard value of 0.71025 . Values of ${ }^{86} \mathrm{Sr} /{ }^{87} \mathrm{Sr}$ ratios in samples from surface gravity core 98-10 are given in Appendix 6, and those from piston core 96-2 are given in Appendix 10.

\section{Sediment Traps}

Time-marking sediment traps that dispense teflon granules in the collection tube every 30 days (Anderson, 1977, figure 6) were suspended at $10 \mathrm{~m}$ below the surface of the lake (surface trap) and $2 \mathrm{~m}$ above the bottom of the lake (bottom trap) at three different localities (fig. 1), in up to $40 \mathrm{~m}$ of 


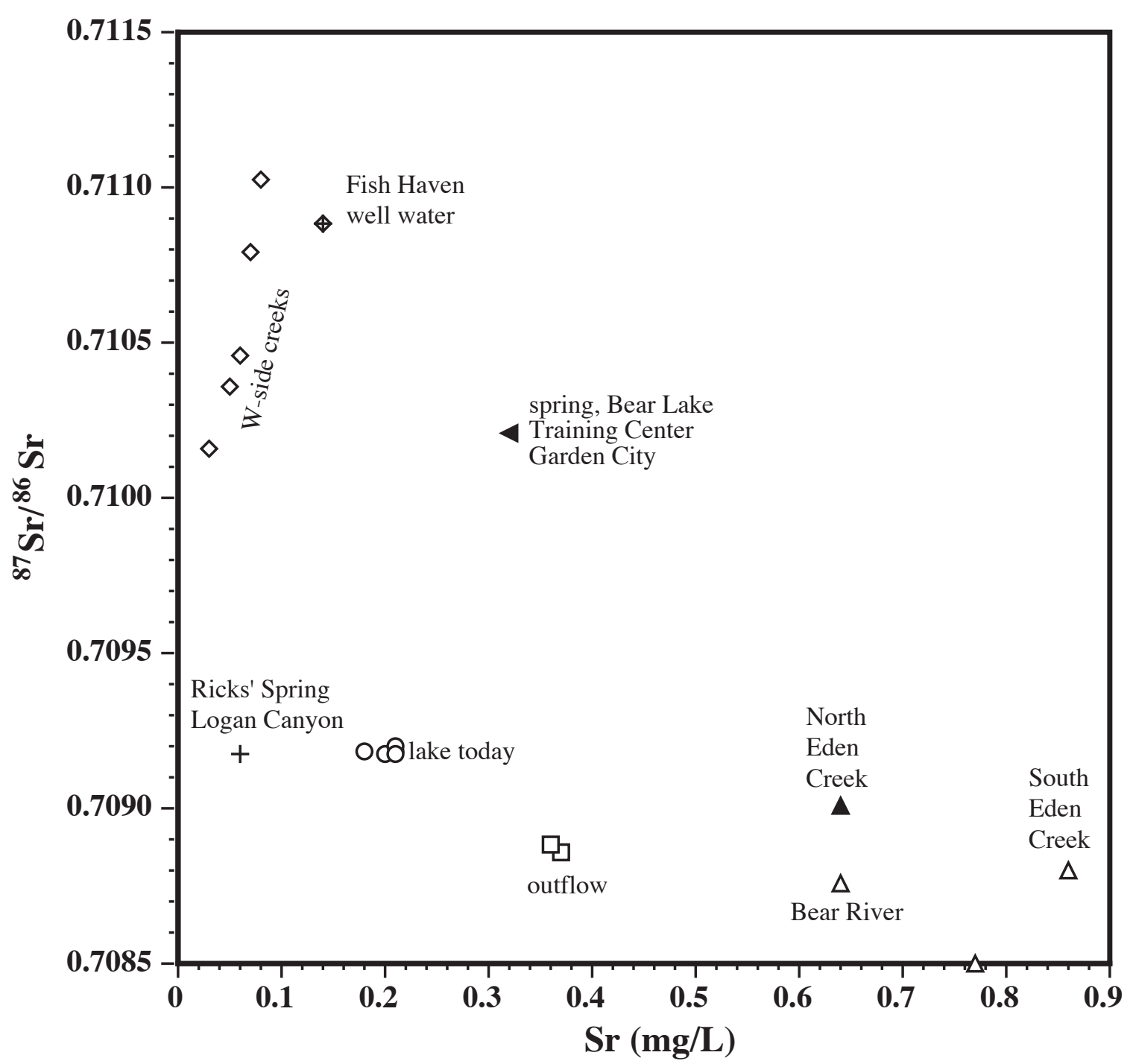

Figure 5. Cross plot of concentration of $\mathrm{Sr}$ and the ${ }^{87} \mathrm{Sr} /{ }^{86} \mathrm{Sr}$ ratio in Bear Lake and associated waters. All values are from Table 1.

water for a period of three years. Summer carbonate sediment collected in all surface traps consists of almost pure high-Mg calcite (ca. 10 mole \% Mg) (figs. 7 and 8). Summer sediment collected in bottom traps typically consists of aragonite or calcite as the dominant mineral, with varying amounts of quartz and minor dolomite (Appendix 2). Aragonite usually was the dominant mineral in sediments collected in the bottom trap at the deepest, basin-center site (site 2, Figs. 1 and 7), whereas calcite usually was the dominant mineral in sediments collected in the bottom trap at the shallowest site at the north end of the lake (site 3, Figs. 1 and 8). The aragonite occurs as needle-shaped crystals about $5 \mu \mathrm{m}$ long and $<1 \mu \mathrm{m}$ in diameter. The calcite occurs as equant, rounded rhombohedral grains about $4-5 \mu \mathrm{m}$ in diameter. A surprising observation, however, was that calcite in the bottom traps consisted of varying proportions of high- $\mathrm{Mg}$ calcite and low- $\mathrm{Mg}$ calcite (figs. 7 and 8). This suggests that the high-Mg calcite precipitated in surface waters is being transformed to low-Mg calcite as it falls through the water column. This transformation from high-Mg calcite to low-Mg calcite continues in the surface sediments, and high-Mg calcite is gone by about $10 \mathrm{~cm}$ below lake floor (cmblf).

$\mathrm{HCl}$-leach-chemistry, strontium-isotope, and carbon- and oxygen-isotope techniques were applied to samples of bulk sediment from the traps to see if these data revealed any differences that might help to explain the differences in mineralogy between surface and bottom traps. The leach-chemistry results (Bischoff and others, 2005) are consistent with the mineralogy. The high-Mg calcite-rich sediments in the surface traps contain about twice as much $\mathrm{Mg}$ as the aragonite-rich sediments 


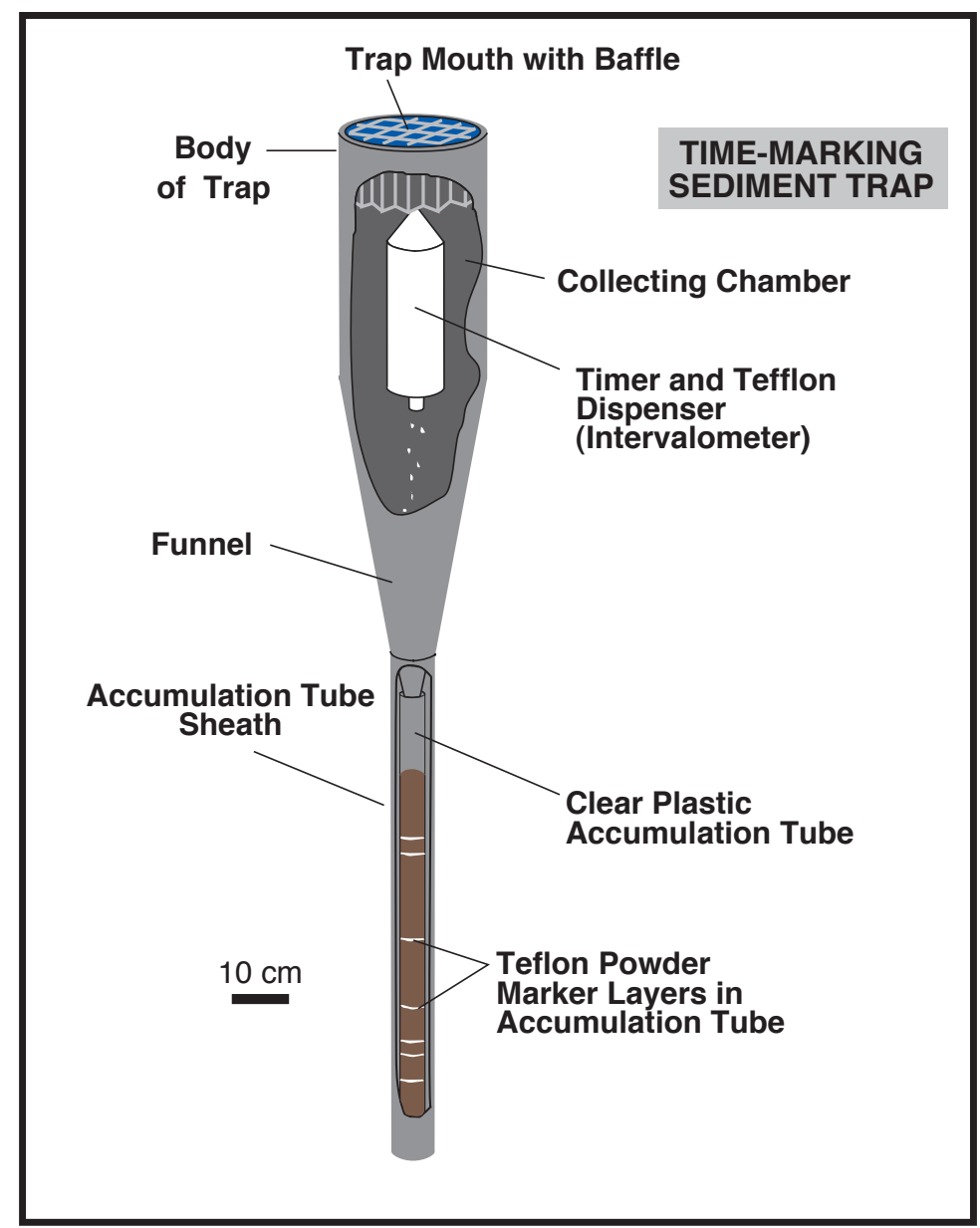

Figure 6. Cross section of a time-marking sediment trap of the design by Anderson (1977).

of the bottom traps, whereas the sediments in the bottom traps contain about twice as much $\mathrm{Sr}$ and are slightly enriched in $\mathrm{Ba}$ (figs. 7 and 8).

Values of ${ }^{87} \mathrm{Sr} /{ }^{86} \mathrm{Sr}$ in bulk carbonate (Appendix 2) in sediments in surface traps are close to those for Bear Lake water (0.7092, Appendix 1). Values of ${ }^{87} \mathrm{Sr} /{ }^{86} \mathrm{Sr}$ in sediments in bottom traps are slightly higher (0.7093-0.7094) close to those for surface sediments.

Values of $\delta{ }^{18} \mathrm{O}$ and $\delta{ }^{13} \mathrm{C}$ in bulk-sediment samples (Appendix 2) show a distinct evolutionary trend of enrichment in both ${ }^{18} \mathrm{O}$ and ${ }^{13} \mathrm{C}$ going from surface traps to bottom traps (fig. 9). This trend parallels the evolutionary mineralogical trend of high-Mg calcite in surface traps to aragonite plus mixed calcite in bottom traps discussed above.

\section{Surface Sediments}

Cores of surface sediment (up to $50 \mathrm{~cm}$ ) were collected with a gravity corer in 1998 (fig. 1) from the sites of two of the three piston cores that were collected in 1996 (sites 1 and 2, fig. 1). In addition, surface-sediment cores were collected from the north end of the lake (site 3, fig. 1), where we had no piston core, in order to better assess changes in sediment composition following the diversion of Bear River into Bear Lake over the period 1909-1918. Four parallel cores were taken at each of the three locations. One core from each site, usually the longest (cores 98-06, 98-10, and 98-12, fig. 1), was extruded from the clear plastic liner at $1-\mathrm{cm}$ intervals into petri 
dishes. The 1-cm slices were sent to USGS laboratories in St. Petersburg, Florida, for $210 \mathrm{~Pb}$ dating. Aliquots of the remaining sediment from each 1-cm interval were sent to USGS laboratories in Denver, Colorado, for analyses of carbons, XRD mineralogy, and strontium-isotopes, and to USGS laboratories in Menlo Park, California, for HCl-leach chemistry (Bischoff and others, 2005). The second core went to the USGS laboratories in Salt Lake City, Utah, for analyses of contaminants. The third core went to Dr. Katrina Mosier, University of Utah, for analyses of diatoms. The fourth core went to Dr. Darrell Kaufman, University of Northern Arizona, for analyses of ostracodes and amino-acid dating. Aliquots of sediments from the ostracode cores (98-06, 98-09, and 98-13, fig. 1) were sent to the Limnological Research Center, University of Minnesota, for analyses of carbons and carbon and oxygen isotopes.

\section{Mineralogy}

One of the main reasons for obtaining an undisturbed record of surface sediments was to see how the sediment record responded to a major change in water chemistry that occurred when the Bear River was diverted into Bear Lake in the early part of the $20^{\text {th }}$ century. Prior to diversion, there is no historical record of the Bear River ever entering Bear Lake naturally. Not much is known about the water chemistry of Bear Lake prior to diversion, but an analysis of water collected in 1912 (Kemmerer and others, 1923) showed concentrations of total dissolved solids (TDS), Mg, and Ca of 1060, 152, and $4.1 \mathrm{mg} / \mathrm{L}$, respectively (Appendix 1). Corresponding values in Bear Lake today are 500, 53, and 31, respectively. In other words, the salinity of the lake is about half of what it was in 1912, and the $\mathrm{Mg} / \mathrm{Ca}$ ratio has gone from 37 to 1.7. Surely, such changes should have had a large effect on carbonate minerals precipitating in the lake and the chemistry of those minerals.

Analyses of cores of surface sediments $(30-50 \mathrm{~cm})$, dated by ${ }^{210} \mathrm{~Pb}$, from the same three localities in the lake as the sediment traps indicate that changes in carbonate mineralogy and chemistry were not always as profound as we would have expected. There is little difference in the percentages of total $\mathrm{CaCO}_{3}$ content before and after diversion (Appendix 3 , fig. 10). The percentages of $\mathrm{CaCO}_{3}$ and $\mathrm{OC}$ in sediments decreased somewhat after diversion, but the most pronounced changes were the marked increases in mass accumulation rates (MAR, fig. 10) of all components due to a large increase in bulk-sediment MAR following diversion. In two of the three cores (BL-98-06 and BL98-12, fig. 11), the aragonite contents, relative to those of calcite, actually increases after diversion. Dolomite is a persistent but minor component, and quartz is a major component, in all three cores (Appendix 4, fig. 11).

\section{Isotope geochemistry}

The most abrupt pre-/post-diversion changes appear in the isotopic composition of bulk carbonate (fig. 12). Values of $\delta{ }^{18} \mathrm{O}, \delta{ }^{13} \mathrm{C}$, and ${ }^{87} \mathrm{Sr} /{ }^{86} \mathrm{Sr}$ in bulk carbonate decrease abruptly and markedly in post-diversion sediments (Appendix 5, fig. 12) reflecting the more $18 \mathrm{O}-, 13 \mathrm{C}$-, and ${ }^{87} \mathrm{Sr}$-depleted waters of Bear River. Sediments deposited prior to diversion have values of $\delta{ }^{18} \mathrm{O}$ of about $-4 \%$, whereas the carbonates that precipitated in the less saline waters of the lake after diversion have values of $\delta{ }^{18} \mathrm{O}$ of -7 to $-7.5 \%$, slightly more enriched in ${ }^{18} \mathrm{O}$ than in sediments from bottom traps (fig. 7). Values $\delta$ ${ }^{13} \mathrm{C}$ in prediversion sediments are 2.5 to $3 \%$, whereas those of post-diversion sediments are $<1 \%$ (fig. 12).

Values of ${ }^{87} \mathrm{Sr} /{ }^{86} \mathrm{Sr}$ in carbonates deposited before diversion are around 0.7102 (Appendix 5; fig. 12), similar to values in stream and spring waters today on the west side of the lake (fig. 5). Values of ${ }^{87} \mathrm{Sr} /{ }^{86} \mathrm{Sr}$ in carbonates deposited in the lake after diversion are around 0.7094, similar to those of Bear Lake water today, but higher than those of Bear River (ca. 0.7088; fig. 5). The results for pre- and post-diversion sediments in core BL98-10 (fig. 12) suggest that the pre-diversion Bear Lake had a higher $\mathrm{Mg}$ concentration but a lower $\mathrm{Sr}$ concentration, and the $\mathrm{Sr}$ was enriched in ${ }^{87} \mathrm{Sr}$.

\section{Glacial to Holocene Changes in Sedimentation}

Kullenberg piston cores collected in 1996 were only able to penetrate up to $5 \mathrm{~m}$, but this was sufficient to collect sediments deposited over the last 30,000 years, well beyond the last glacial interval (LGI, 24,000 to 10,000 years B.P.). The radiocarbon chronologies for these cores are described in Colman and others (2005). As seen on figure 2, the sedimentary sequence in Bear Lake consists of a series of eastward dipping strata, the shallowest of which pinch out to the west. Therefore, the three cores that we collected (96-1, 96-2, and 96-3, fig. 1) contain overlapping sequences. This can be seen in the profiles of calcite and aragonite versus depth shown in Figure 13. The aragonite-dominated sediment deposited over the last 7000 years is present in $500 \mathrm{~cm}$ of section in core 98-1 and in $170 \mathrm{~cm}$ of section in core 96-2. Apparently the bottom of 96-1 just missed the top of the calcite-dominated sequence that occurs at 170-200 cm in 96-2. Most of the Holocene section is missing from the top of 96-3. Core 96-2 contains all of the lithologic units deposited over the last 26,000 cal yr BP in Bear Lake.

\section{Mineralogy}

The sediments consist predominantly of aragonite, calcite, dolomite, and quartz. Percentages of these minerals calculated from XRD peak heights (Appendix 8.1., 8.2., and 8.3.) are plotted versus depth on figure 14. The data for core 96-3 (fig. 14) show that the carbonate-poor section deposited during the LGI (below $40 \mathrm{~cm}$ ) consists of about $60-80$ percent quartz, 10-20 percent calcite, and minor feldspar and dolomite. The quartz and feldspar are detrital brought in by the 


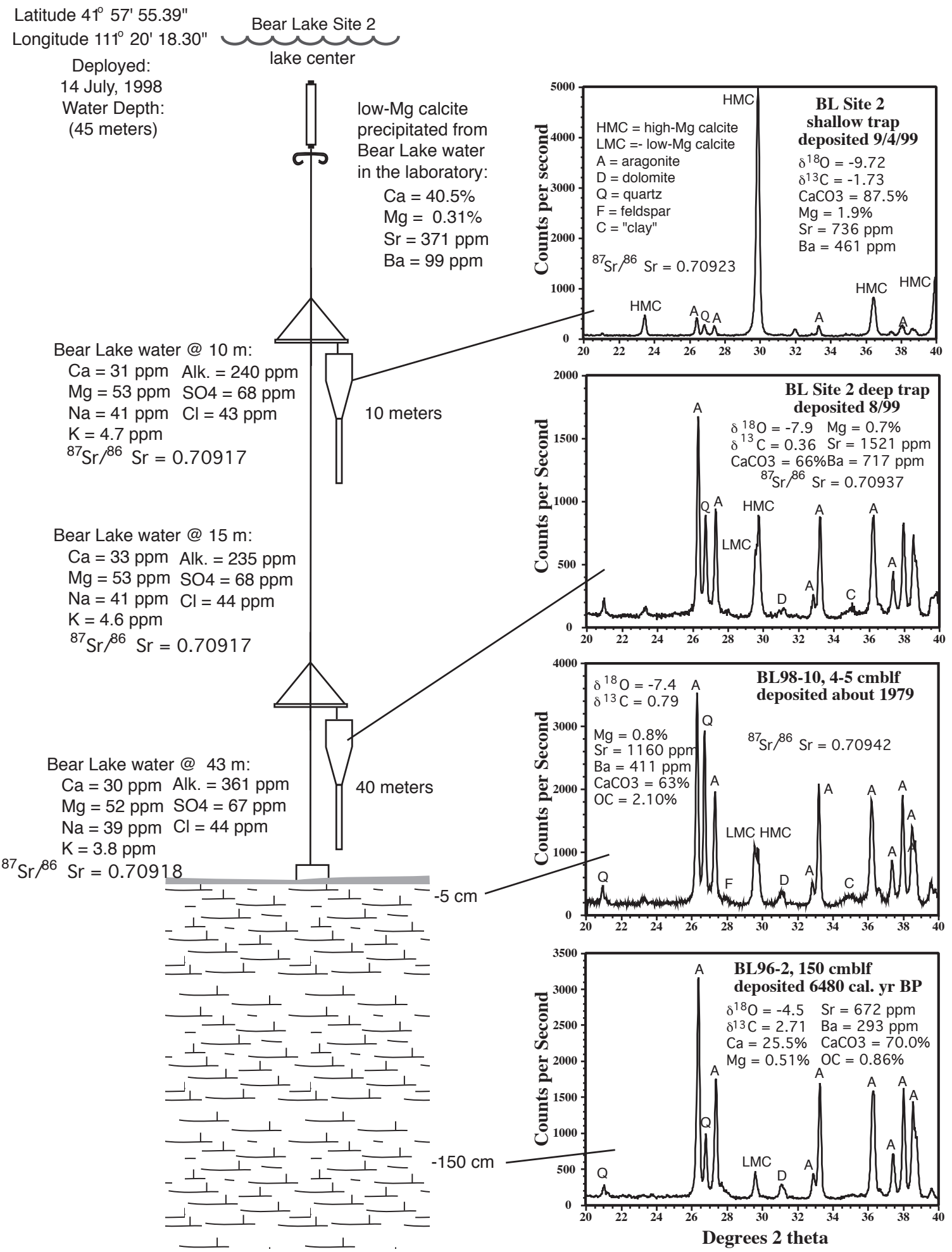

Figure 7. Diagram showing the placement of surface $(10 \mathrm{~m})$ and bottom $(40 \mathrm{~m})$ sediment traps at site 2 (Fig. 1) in the center of Bear Lake in a water depth of $45 \mathrm{~m}$. Results of chemical analyses of water from depths of $10 \mathrm{~m}$, $15 \mathrm{~m}$, and $43 \mathrm{~m}$ are shown to the left of the trap diagram. X-ray diffractograms and geochemical analyses of samples of bulk sediment from the two traps, from $4-5 \mathrm{~cm}$ in short core $98-10$, and from $150 \mathrm{cmblf}$ ( $3700 \mathrm{cal} \mathrm{yr} \mathrm{BP)}$ in piston core 96-2 are shown to the right of the trap diagram. Leach chemistry of low-Mg calcite precipitated from Bear Lake water in the laboratory is shown at the top-center of the illustration. 


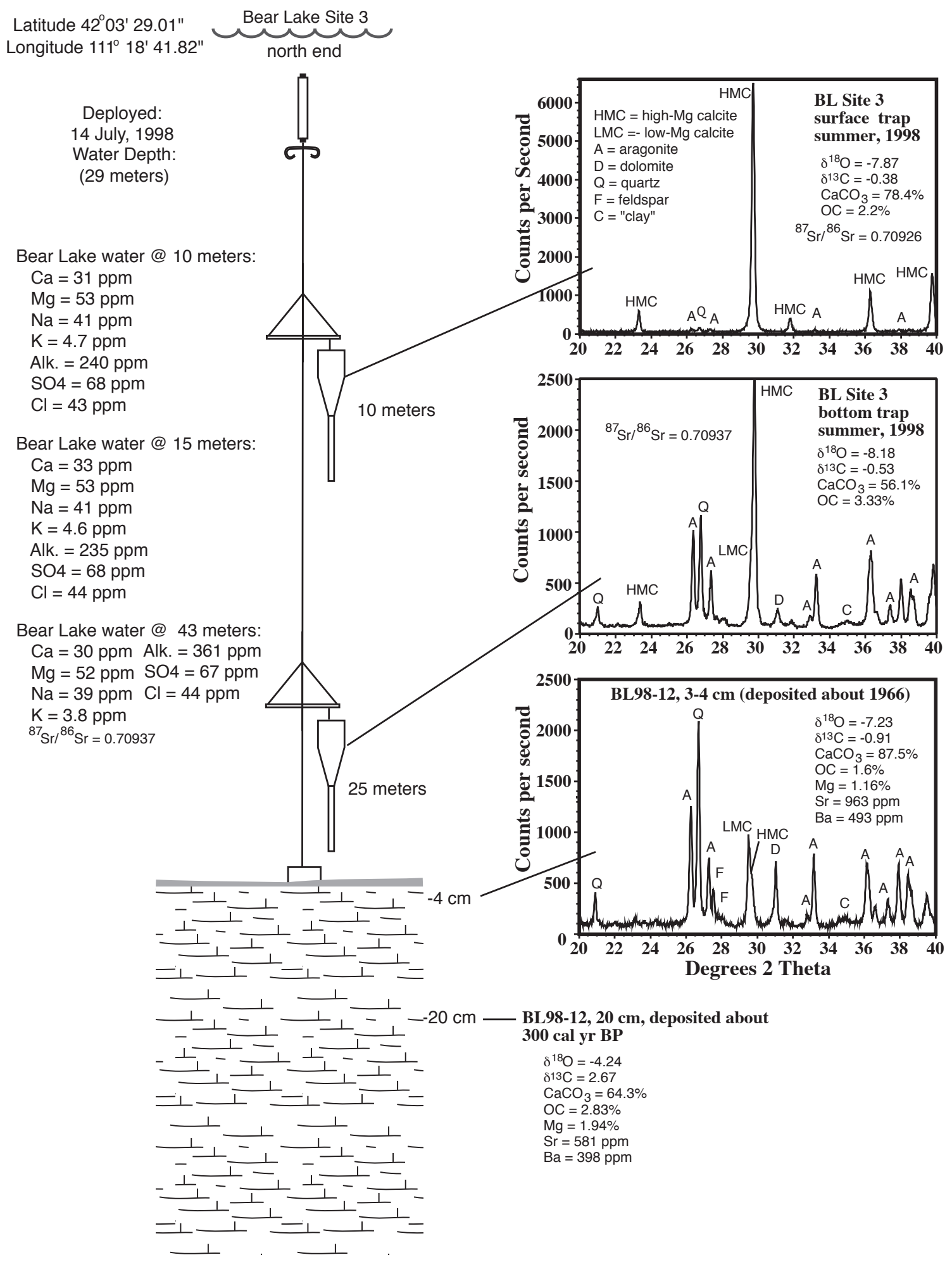

Figure 8. Diagram showing the placement of surface $(10 \mathrm{~m})$ and bottom $(25 \mathrm{~m})$ sediment traps at site 3 (Fig. 1) at the north end of Bear Lake in a water depth of $29 \mathrm{~m}$. X-ray diffractograms and geochemical analyses of samples of bulk sediment from the two traps, and from 3-4 $\mathrm{cm}$ in short core 98-12 are shown to the right of the trap diagram. 


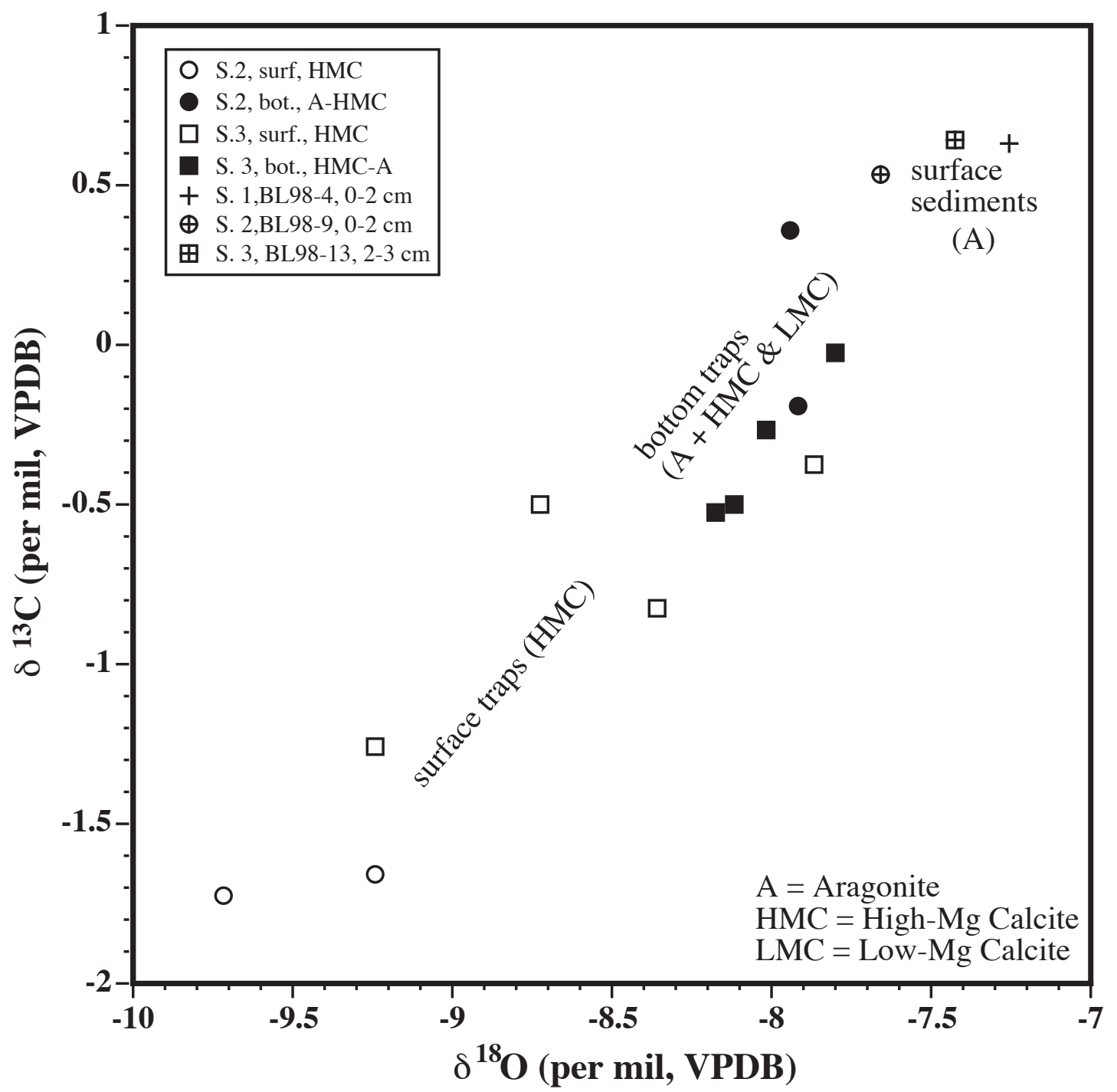

Figure 9. Cross plot of values of $\delta^{18} 0$ and $\delta^{13} \mathrm{C}$ in carbonate in bulk-sediment samples from shallow and deep sediment traps at sites 2 and 3 (Figs. 1, 7, and 8), and from the tops of cores 98-06, -10, and -12 collected at sites 1, 2, and 3 (Fig. 1).

Bear River during the LGI when the river was connected to Bear Lake. Some, or perhaps all, of the calcite and dolomite also might be detrital, but we have no way of knowing how much. These LGI sediments consist of red silty clay that are in marked contrast to the light-tan carbonate-rich Holocene sediments, regardless of mineralogy.

The carbonate-rich sediments deposited since $14,000{ }^{14} \mathrm{C}$ yr BP exhibit several abrupt changes in mineralogy (calcite and aragonite, fig. 13, core 96-2). These changes in mineralogy are not always reflected in the overall percent $\mathrm{CaCO}_{3}$ (fig. 14). The percentage of $\mathrm{CaCO}_{3}$ began to increase at about 320 cm (fig. 15, core 96-2, ca. 17,000 cal yr BP), reached a plateau of about 40 percent between 300 and $250 \mathrm{~cm}$, then increased to about 70 percent by $240 \mathrm{~cm}$ (ca 12,000 cal yr BP) where it remained throughout the Holocene and through changes in mineralogy. This suggests that there was a mass balance of total $\mathrm{CaCO}_{3}$ that was maintained through changes in mineralogy, which presumably reflect changes in environmental conditions.

The amount of OC that was buried in Bear Lake sediments began to increase at about $340 \mathrm{~cm}$ (fig. 15, core 96-2; ca, 20,000 cal yr BP), reached a plateau of about 1.5-2 percent at about $310 \mathrm{~cm}$ (ca, 16,000 cal yr BP), and then decreased slightly throughout the Holocene. This suggests 

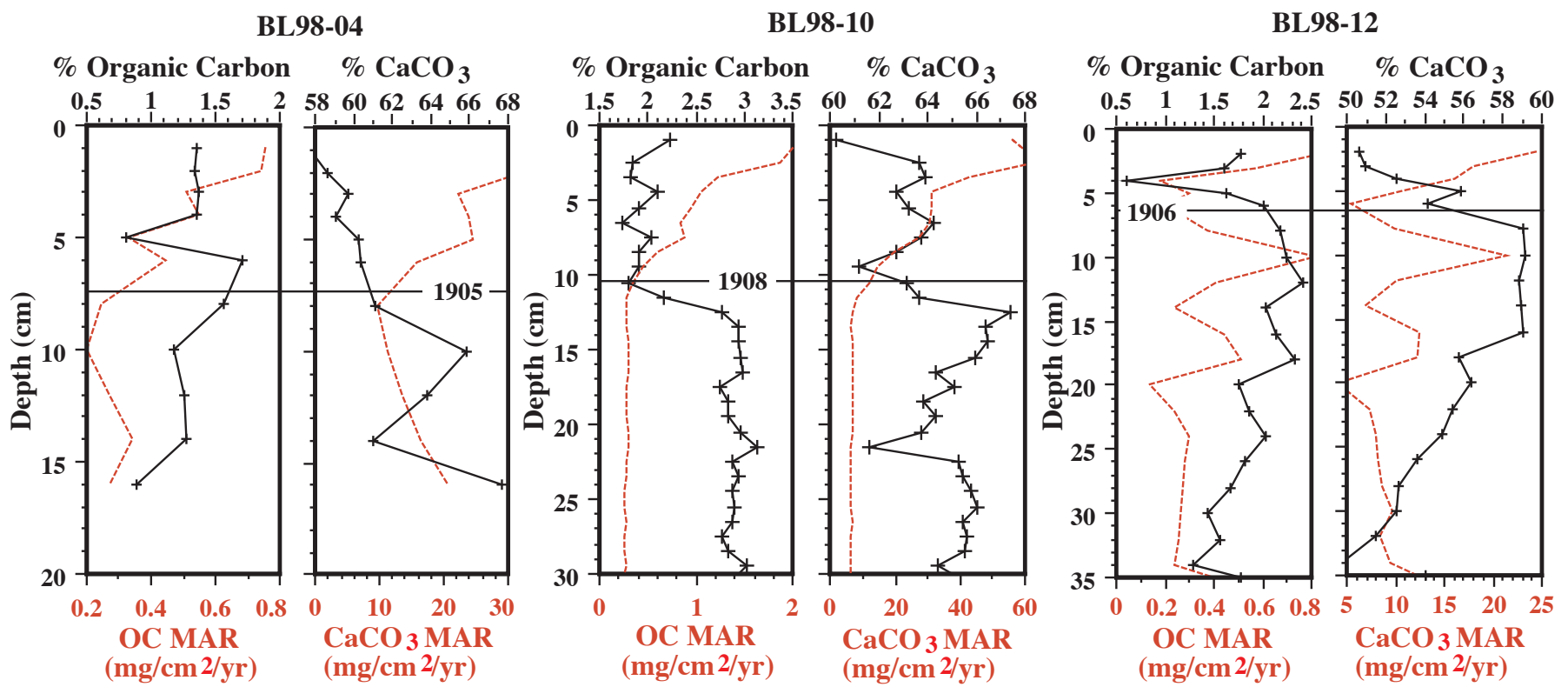

Figure 10. Concentrations (solid lines with plus symbols) and mass accumulation rates (MAR; dashed lines) of organic carbon (OC) and $\mathrm{CaCO}_{3}$ versus depth in centimeters below lake floor (cmblf) in cores 98-04, -10, and -12 (Fig. 1). Selected ${ }^{210} \mathrm{~Pb}$ dates (in years AD) from the beginning of the $20^{\text {th }}$ century are shown for each core.

that perhaps the increase in carbonate precipitation was triggered by increased primary production with a related increase in $\mathrm{pH}$ of the surface waters.

\section{Isotope Geochemistry}

Based on the strontium isotopic composition of waters (fig. 5), we showed that the outflow from Bear Lake can be explained by simple mixing of Bear Lake and Bear River waters. Similarly, the strontium isotopic composition of $20^{\text {th }}$ century carbonates in Bear Lake sediments can be explained by simple mixing of Bear River water with some prediversion lake water with an isotopic composition defined by prediversion, late Holocene carbonate (fig. 12). Therefore, if Bear River entered Bear Lake in the past, the carbon, oxygen, and strontium isotopic composition of carbonates should, as a first approximation, provide evidence of such an event. In particular, the very low values of ${ }^{87} \mathrm{Sr} /{ }^{86} \mathrm{Sr}$ in Bear River water (Appendix 1, fig. 5) should be an excellent tracer (Bouchard and others, 1998). For Bear Lake without Bear River, the hydrology of the lake can be assumed, as a first approximation, to be the main control on isotopic composition. The balance between precipitation and evaporation is one, and perhaps the largest hydrologic factor, but, as discussed earlier, there is an unknown Ca-rich, $\mathrm{Mg}$-rich ground-water source that may have varied considerably with time.

Values of $\delta{ }^{18} \mathrm{O}$ in calcite in the red, quartz-rich LGI sediments are lower (-9\%o, fig. 16; core 96-2) than carbonate that accumulated in Bear Lake since the Bear River diversion (-8\%, fig. 12). This is because during the LGI the lake contained a much larger proportion of ${ }^{18} \mathrm{O}$-depleted Bear River water so any endogenic carbonate would be ${ }^{18} \mathrm{O}$-depleted, and detrital carbonate from Paleozoic carbonate rocks also is ${ }^{18} \mathrm{O}$-depleted. Increases in values of $\delta{ }^{18} \mathrm{O}$ and $\delta{ }^{13} \mathrm{C}$ between 20 and 18 cal. ka could be due to a decrease in the flow of Bear River into the lake or an increase in evaporation. There is no decrease in the accumulation rate of red clay during this interval to suggest decreased river flow, so increased evaporation seems more likely. Values of $\delta{ }^{13} \mathrm{C}$ increased steadily into the Holocene, likely due to increased burial of ${ }^{13} \mathrm{C}$-depleted $\mathrm{OC}$ as indicated by the rapid increase in percent $\mathrm{OC}$ (fig. 15). Between 320 and $300 \mathrm{~cm}$, values of $\delta{ }^{18} \mathrm{O}$ declined to $-11 \%$, the lowest values in the entire glacial-Holocene sequence (fig. 16, core 96-2). These lower values might be due to greater influx of Bear River water, but there is no corresponding decrease in values of ${ }^{87} \mathrm{Sr} /{ }^{86} \mathrm{Sr}$ (fig. 16, core 96-2). Therefore, these low values are most likely due to warming water temperatures at the end of the LGI. 

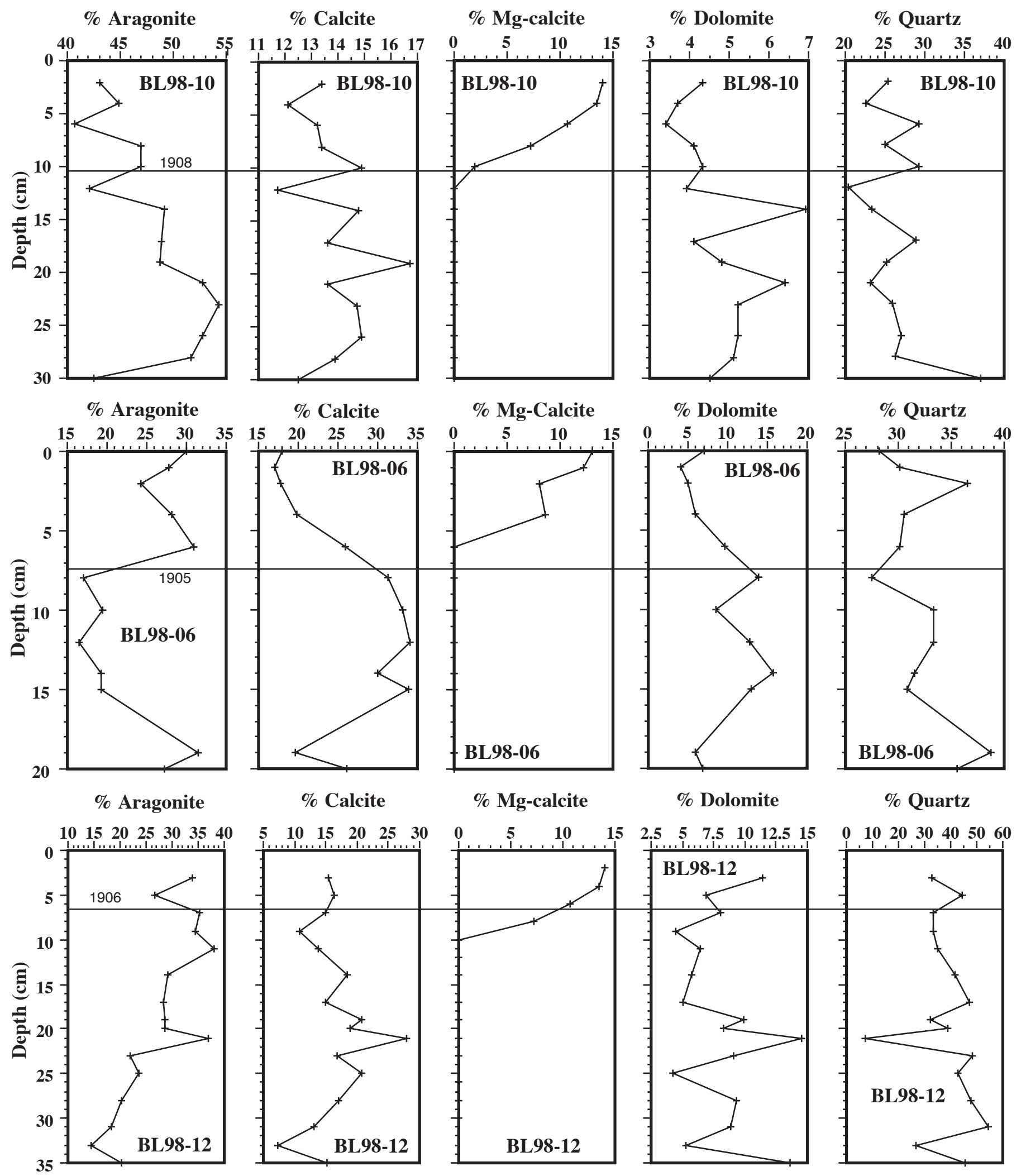

Figure 11. Concentrations of aragonite, calcite, high-Mg calcite, dolomite, and quartz, calculated from XRD peak heights, versus depth in cores 98-06, 98-10, and 98-12 (Fig. 1). Selected 210 Pb dates (in years AD) are shown for each core. 

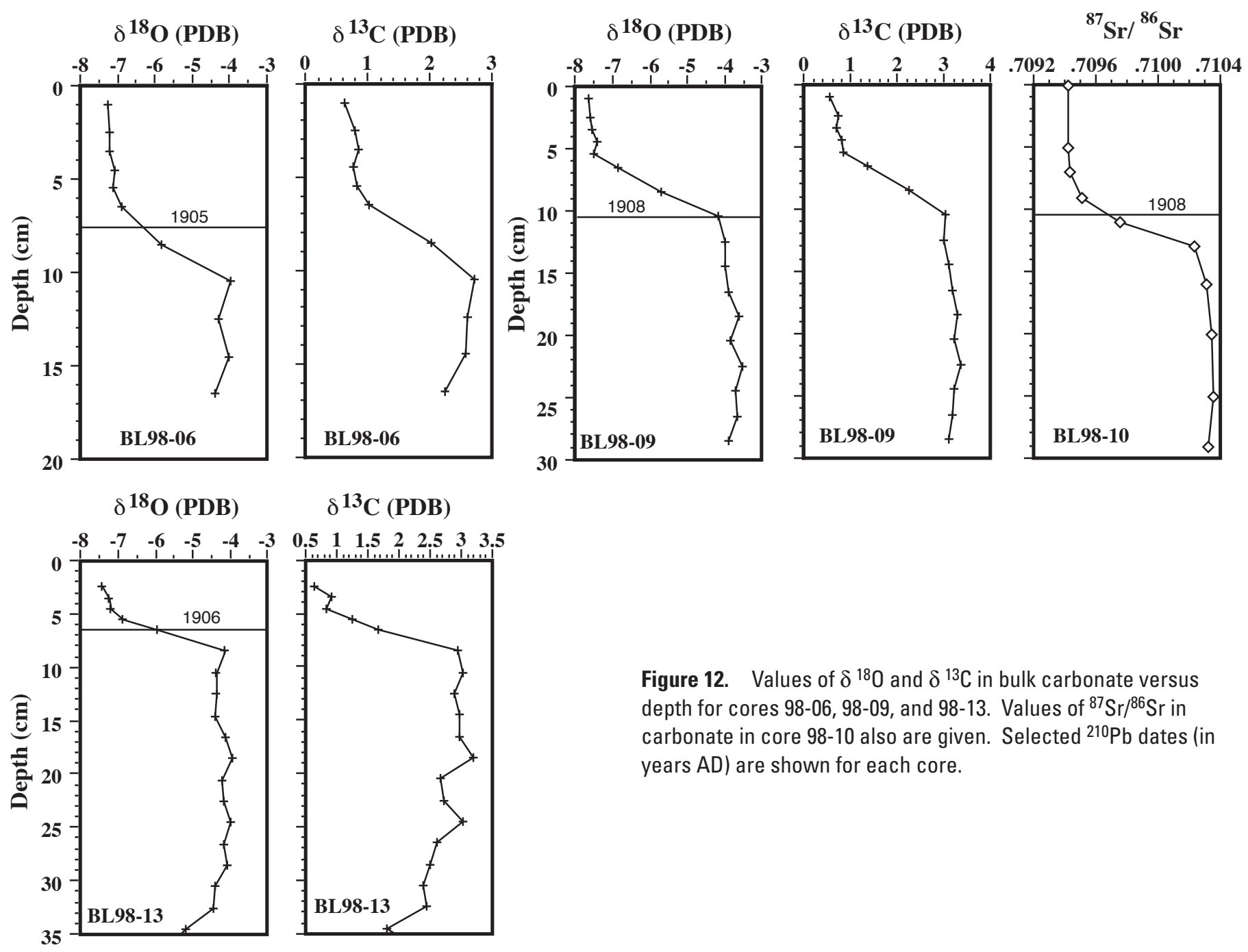

Figure 12. Values of $\delta^{18} 0$ and $\delta^{13} \mathrm{C}$ in bulk carbonate versus depth for cores 98-06, 98-09, and 98-13. Values of ${ }^{87} \mathrm{Sr} /{ }^{86} \mathrm{Sr}$ in carbonate in core $98-10$ also are given. Selected ${ }^{210} \mathrm{~Pb}$ dates (in years $A D$ ) are shown for each core.

At about $250 \mathrm{~cm}$ (ca, 12,000 cal yr BP), values of both $\delta$ ${ }^{18} \mathrm{O}$ and $\delta{ }^{13} \mathrm{C}$, but especially $\delta{ }^{18} \mathrm{O}$, began to increase rapidly (fig. 16, core 96-2), most likely due to increased evaporation. Between 250 and $220 \mathrm{~cm}$, values of $\delta^{18} \mathrm{O}$ increase by $6 \%$, from - $11 \%$ o to $-5 \%$. Values of ${ }^{87} \mathrm{Sr} /{ }^{86} \mathrm{Sr}$ also increased during this interval (ca 12,000 to 10,000 cal yr BP) (fig. 16). By $10,000 \mathrm{cal}$ yr BP (220 cm in core 96-2), the mineralogy and isotopic composition of bulk carbonate was approaching values that would be typical of most of the Holocene (Figs. 14 and 16, core 96-2).

At a depth of about $205 \mathrm{~cm}$ (ca, 8,500 cal yr BP), there must have been a remarkable decrease in salinity because formation of aragonite began to decrease, being replaced by formation of calcite (fig. 14, core 96-2). Values of $\delta{ }^{18} \mathrm{O}, \delta{ }^{13} \mathrm{C}$, and ${ }^{87} \mathrm{Sr} r{ }^{86} \mathrm{Sr}$ decreased at this time (fig. 16) suggesting that Bear River water again was entering Bear Lake. The lower salinity event lasted about 1500 years, and by 7,000 cal yr BP, aragonite was again forming, and values of $\delta{ }^{18} \mathrm{O}, \delta^{13} \mathrm{C}$, and ${ }^{87} \mathrm{Sr} /{ }^{86} \mathrm{Sr}$ of carbonate were increasing (ca. $170 \mathrm{~cm}$ in core 96-2; figs. 14 and 16). The mineralogy of carbonate in Bear Lake sediments has been relatively constant for the last 7,000 yr (fig. 14), but values of $\delta{ }^{18} \mathrm{O}$ and $\delta{ }^{13} \mathrm{C}$ continued to increase slightly (fig. 16), suggesting that perhaps salinity continued to increase after Bear River was again disconnected from Bear Lake. 


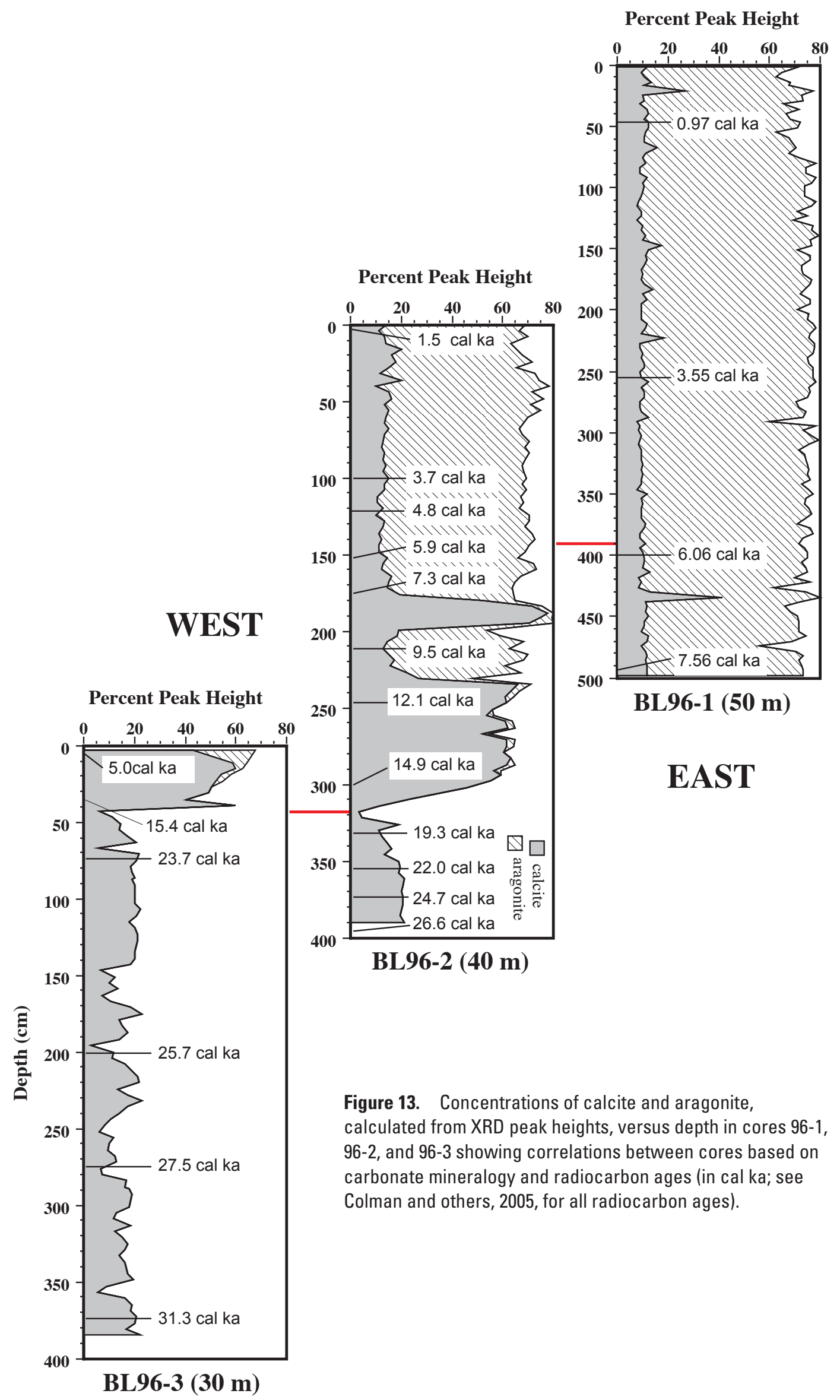


Bear Lake, Core 96-1
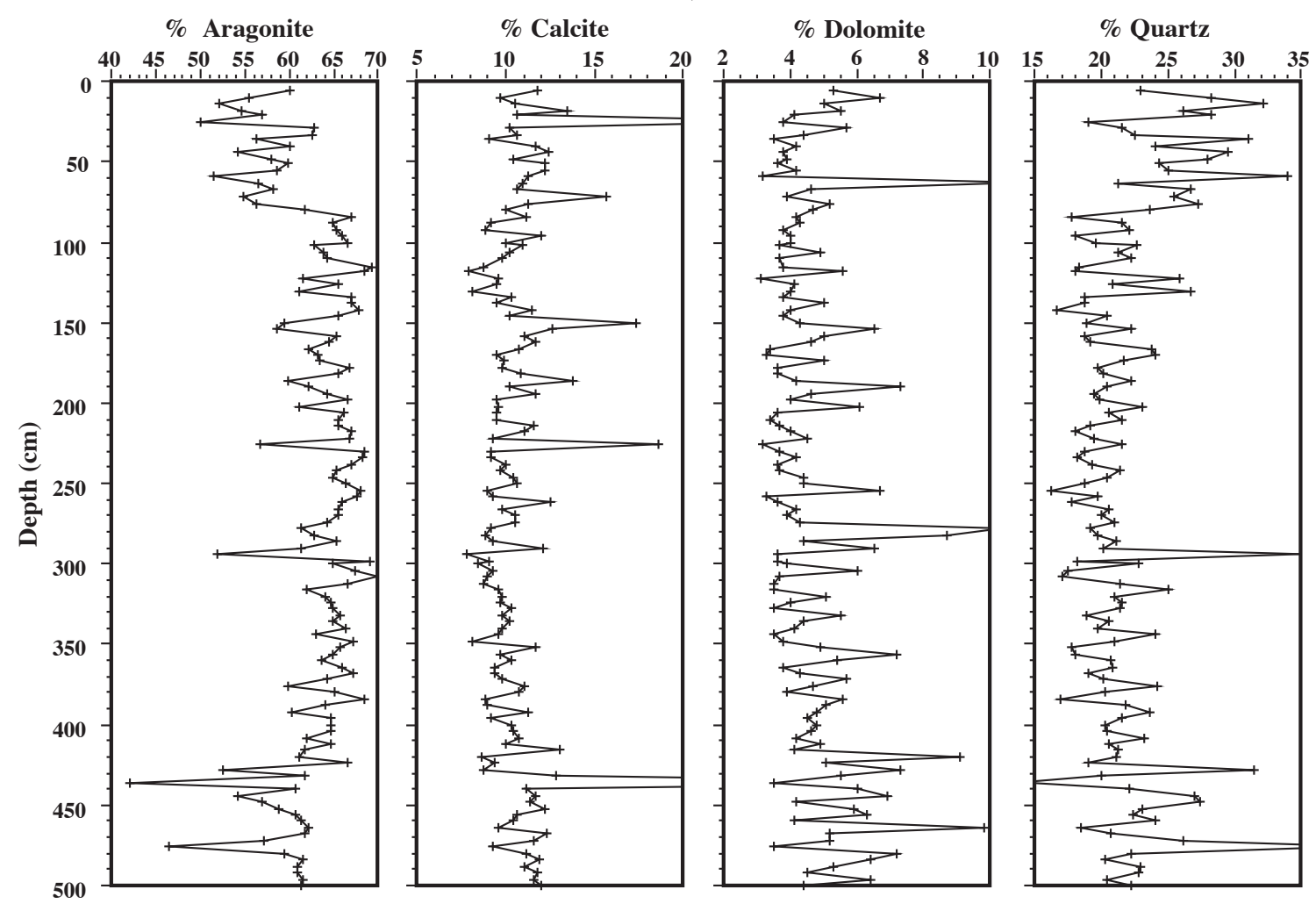

Bear Lake, Core 96-2

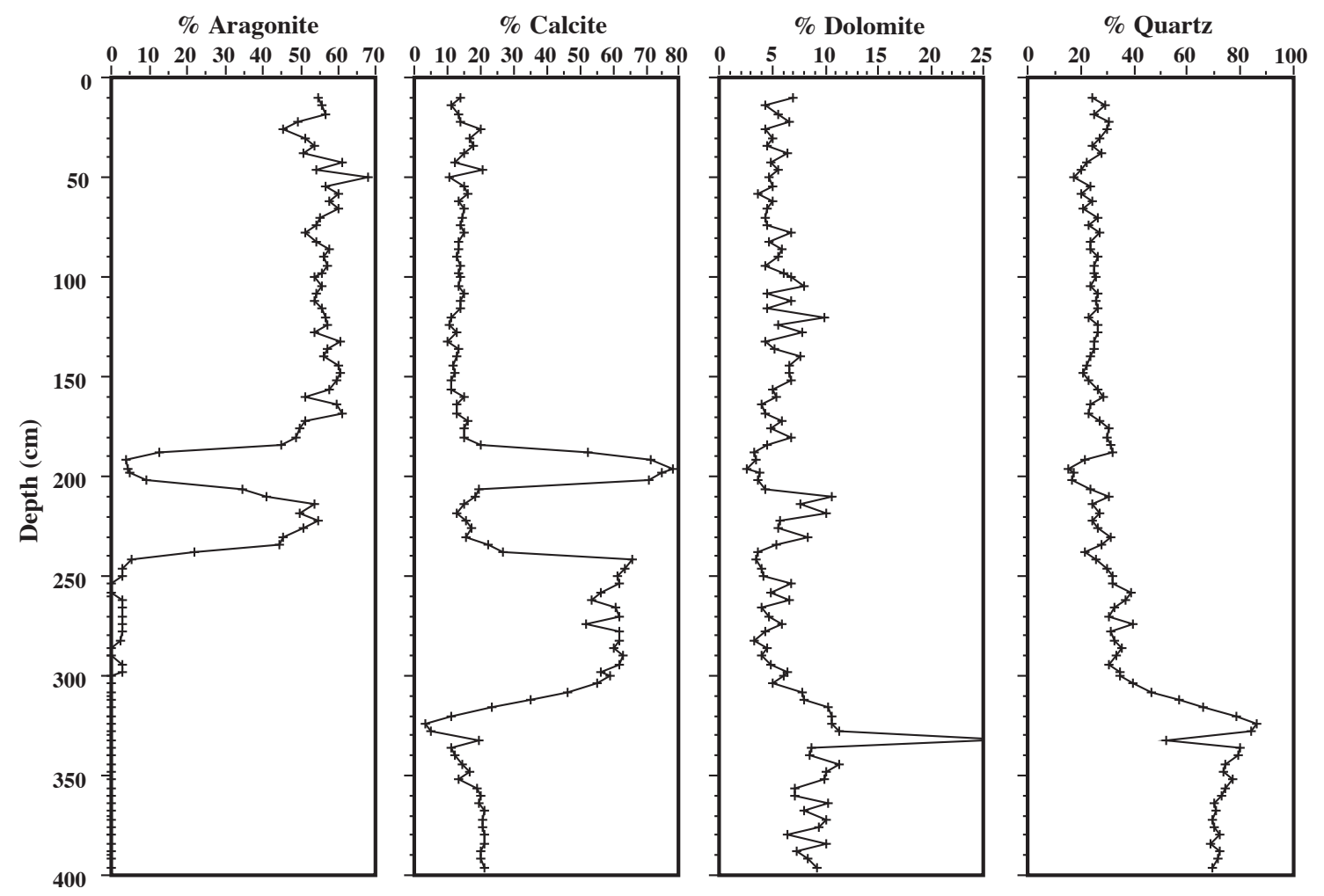

Figure 14. Concentrations of aragonite, low-Mg calcite, dolomite, quartz, and feldspar (core 96-3 only) calculated from XRD peak heights, versus depth, for cores 96-1, 96-2, and 96-3. 
Bear Lake, Core 96-3

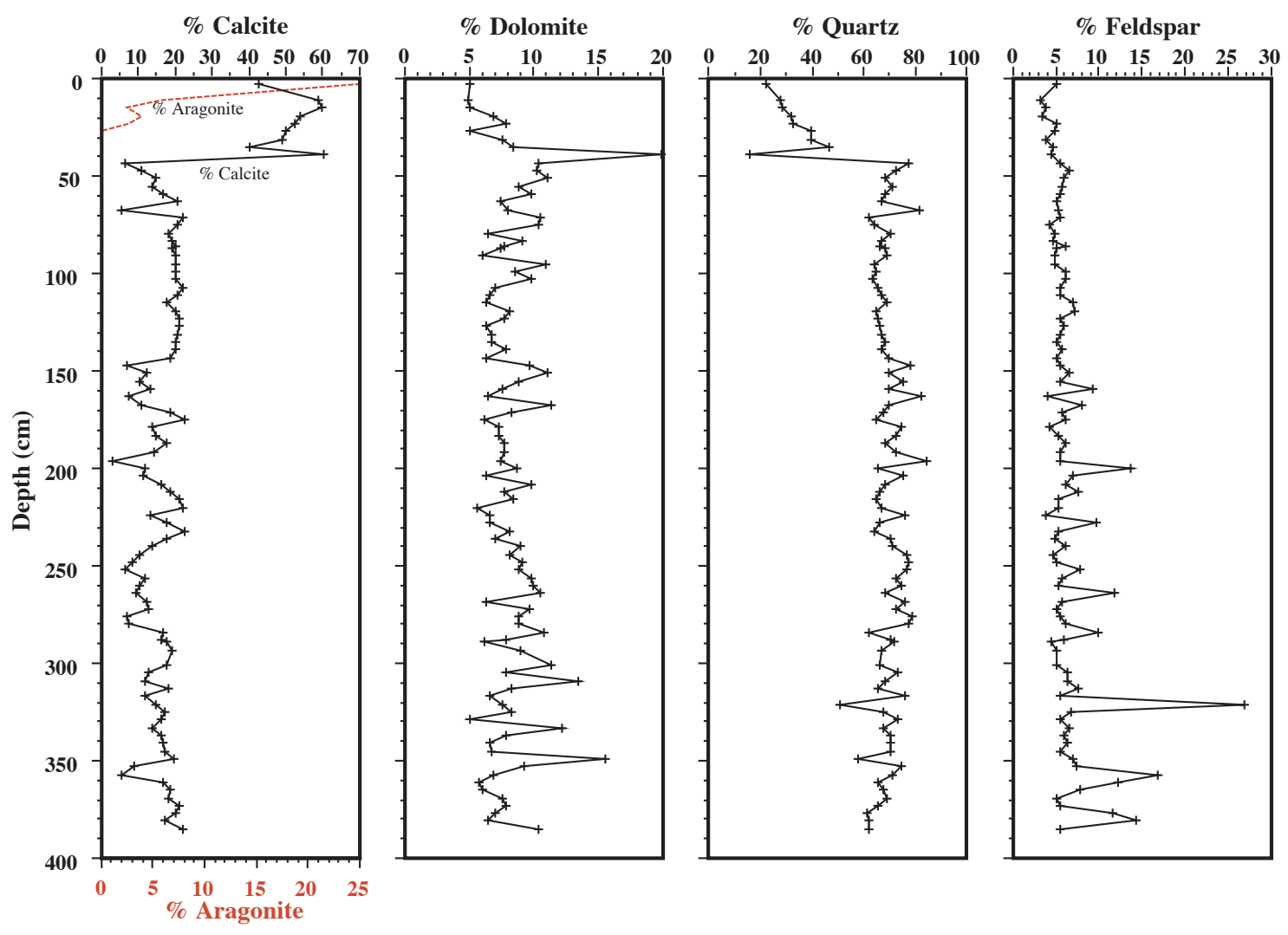

Fiigure 14. Continued.

Bear Lake, Core 96-1

Bear Lake, Core 96-2
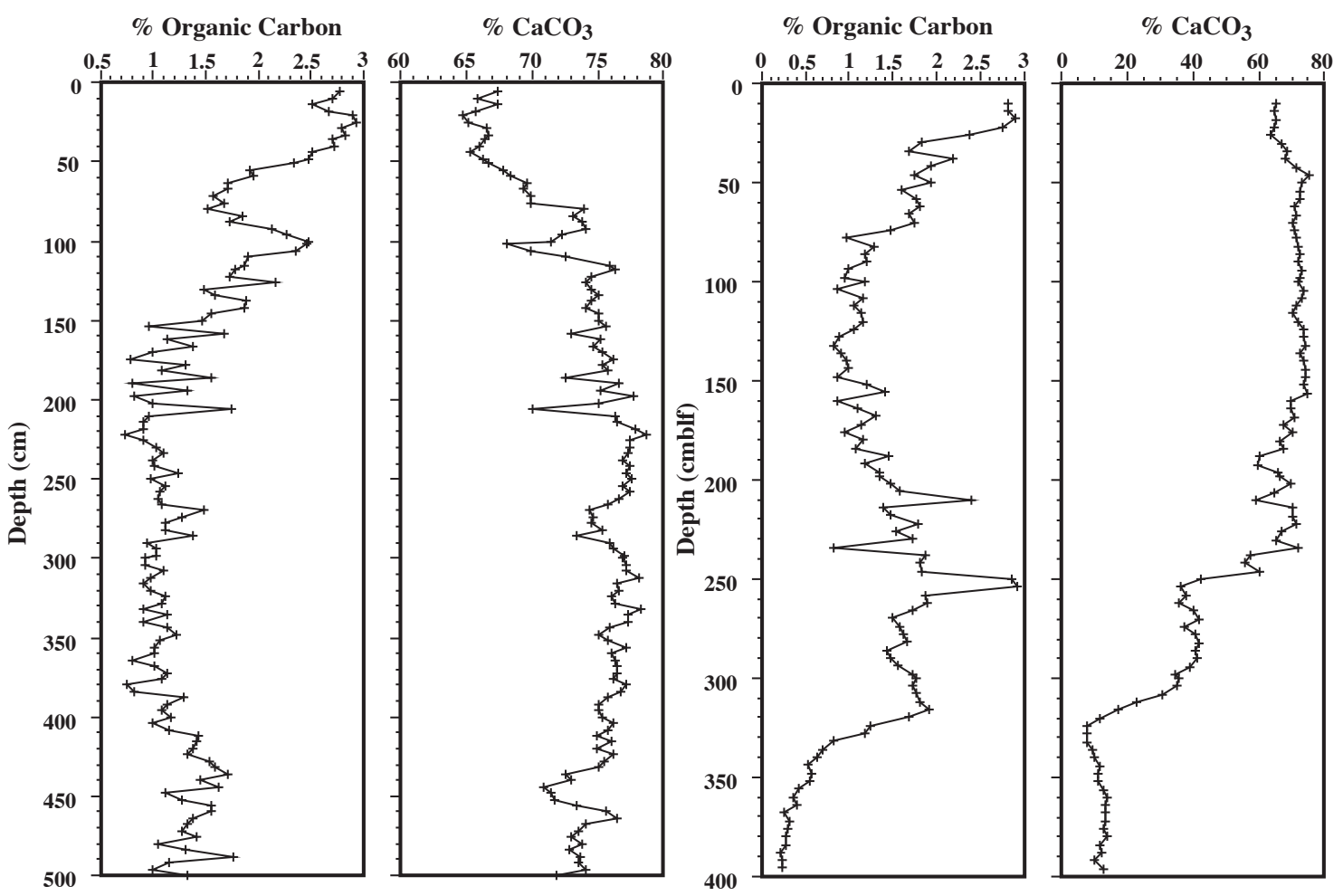

Figure 15. Concentrations of total carbonate, expressed as $\mathrm{CaCO}_{3}$, and organic carbon (OC) versus depth for cores $96-1$ and $96-2$. 


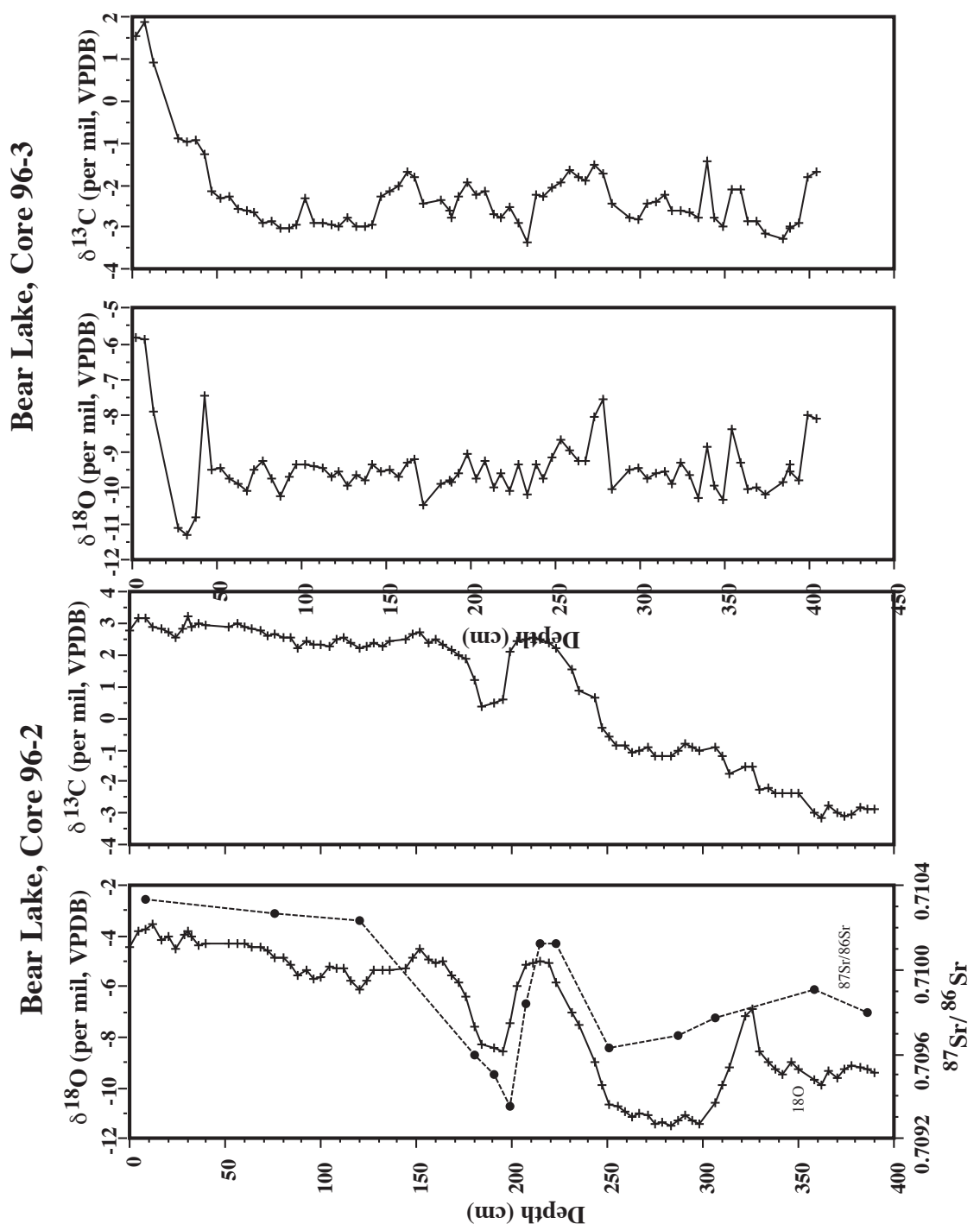

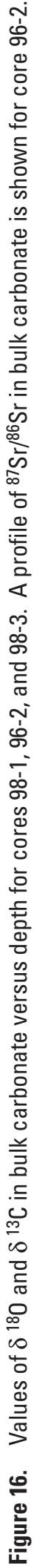




\section{Reference}

Anderson, R.Y., 1977, Short term sedimentation response in lakes in western United States as measured by automated sampling: Limnology and Oceanography, v. 22, p. 423-433.

Birdsey, P.W., 1989, The limnology of Bear Lake, Utah-Idaho, 1912-1988: A literature review: Publication no. 89-5, Utah Department of Natural Resources, Division of Wildlife Resources, 113 pp.

Bischoff, J.L., Cummins, K., and Shamp, D., 2005, Geochemistry of sediments In Bear Lake cores and sediment traps taken in 1996 and 1998: U. S. Geological Survey, Open-File Report

Bouchard, D.P., Kaufman, D.S., Hochberg, A., and Quade, J., 1998, Quaternary history of the Thatcher Basin, Idaho, reconstructed from the ${ }^{87} \mathrm{Sr} /{ }^{86} \mathrm{Sr}$ and ameno acid composition of lacustrine fossils: implications for the diversion of the Bear River into the Bonneville Basin: Palaeogeography, Palaeoclimatology, and Palaeoecology, v. 141, p. 95-114.

Colman, S.M., Kaufman, D.S., Rosenbaum, J.G., and McGeehin, J.P., 2005, Radiocarbon dating of cores collected in Bear Lake, Utah: U. S. Geological Survey, Open-File Report
Engleman, E.E., Jackson, L.L., Norton, D.R., Fischer, A.G., 1985, Determination of carbonate carbon in geological materials by coulometric titration: Chemical Geology, v. 53, p. $125-128$.

Kemmerer, G., Bovard, J.F., and Boorman, W.R., 1923, Northwestern lakes of the United states; biological and chemical studies with reference to possibilities to production of fish: U.S. Bureau of Fisheries Bulletin, v. 39, p. 51-140.

Lamarra, V., Liff, C., and Carter, J., 1986, Hydrology of Bear Lake Basin and its impact on the trophic state of Bear Lake, Utha-Idaho: Great Basin Naturalist, v. 46, p. 690-705.

McConnell, W.J., Clark, W.J., and Sigler, W.F., 1957, Bear Lake, its fish and fishing: Utah Department of Fish and Game, Idaho Department of Fish and Game, and Department of Wildlife Management, Utah State University, 27 p.

Moore, D.M., and Reynolds, R.C., Jr., 1989, X-ray diffraction and identification and analysis of clay minerals: Oxford University Press, 332 pp.

Wurtsbaugh, W., and Luecke, C., 1997, Examination of the abundance and spatial distribution of forage fish in Bear Lake (Utah/Idaho): Final Report of Project F-47-R, Study 5, to the Utah Division of Wildlife Resources, Salt Lake City, Utah, 217 pp. 